\title{
Pre-Service Young Learner English Teachers' Reflection through Simulated Teaching Practice
}

\author{
Luh Diah Surya Adnyani \\ English Education Department \\ Universitas Pendidikan Ganesha \\ Singaraja, Indonesia \\ surya.adnyani@undiksha.ac.id
}

\begin{abstract}
Simulated teaching practice was integrated into Material and Media Development course under Teaching English for Young Learner program in a university of education in Indonesia. This study described 26 pre-service young learner English teachers' reflection from simulated teaching practice videos, peers and lecturer's comment, peers' response cards, and self-reflections. The findings of the study are as follows. First, the participants had never before experienced simulated teaching practice for young learner. Second, they used reflection tools, such as videos, peers and teacher' comments, and observation of peers' presentations, to help them develop their awareness of the skills they employed, the competencies they need to improve, their strengths and weaknesses, as well as the difficulties they found and the decision to solve the problems. The reflection of these less-experienced pre-service teachers through simulated teaching practice promotes their professional growth.
\end{abstract}

Keywords-reflection, pre-service, young learner English teacher, simulated teaching practice.

\section{INTRODUCTION}

Scholars in the area of teaching practice agree that the practice of regular reflection supports teachers' professional growth [1], [2], [3]. It is also agreed that as reflective practitioners, teachers are expected to think analytically and purposefully about their knowledge and skills as well as their students' growth and learning. The reflection makes the teachers learn and evaluate their teaching: they use their knowledge and skill to plan instructions and implement them in the classroom. They continuously do adjustment until learning occurs.

The practice of regular reflection is important for both inservice and pre-service teachers. As future teachers, preservice teachers need to cultivate reflection skills. They need to develop their values, knowledge, and skills to become proficient [4]. The teacher candidates are required to develop an awareness of the skills they employed, the competencies they need to improve, their strengths and weaknesses, as well as the difficulties and the decision to solve the problems. The ability to find and cope with that problem during the teaching practice avoid pre-service teachers to experience discouragement and disappointment [5].

In order to prepare pre-service teachers to be proficient in teaching young learner, simulated teaching practice was integrated into Material and Media Development course in
Teaching English for Young Learner program in a university of education. This case study focuses on pre-service teachers' reflection through simulated teaching practice. From the simulated teaching practice videos, peers' comment, lecturer's comment, and the observation of the classmates' teaching practices, the participants are expected to internalize and cultivate their reflection on what they had learned to prepare them for their professional growth.

\section{LITERATURE REVIEW}

English language proficiency knowledge, and knowledge and skills related to curriculum, syllabus, language testing and assessment, teaching methodology, teaching skills, and material development are acquired by teachers graduated from English Education Department [6]. Some colleges for teacher's training and education offer English for young learners in their curriculum, while some do not. Those teachers are trained to teach in secondary level. Their ability in teaching pre-primary and primary level is largely unknown [6]. For the purpose of this study, pre-primary and primary level roughly from the age of 4 up to 12 years old, for kindergarten and elementary students.

There are issues about "the younger the better" idea and the challenges on the initial implementation of language-ineducation, especially in teaching English for young learners [7]. One of the issues is the primary English teacher. Regular teachers teach English in primary school in China [8], Korea, [7] as well as in Indonesia. It is because those countries lack of fully trained English for young learners teachers. The preservice teachers are prepared to teach in secondary level, not in primary level, although English subject is also inserted in primary curriculum.

To prepare pre-service English teachers to be proficient to teach in pre-school and primary school, and to ensure adequate emphasis on young learner pedagogy [9], a university of education in Indonesia inserted a Teaching English for Young Learner program. One of the courses is Material and Media Development for Young learner course. The purpose of this course is to prepare the pre-service teachers to be able to develop fun, careful, and meaningful material; design interesting media; plan and implement teaching activities as well. The pre-service teachers should not use traditional approach, in which they read aloud a book, 
repeated by the students or write on board and copied by the students [10].

In preparing a professional specialist English teacher to teach young learner, pre-service training in South Korea appears to be successful [7]. In Indonesia, young learner English teachers are trained in a concentration developed within the pre-service system [9]. However, the teaching practice is not in elementary or pre-elementary level. Therefore, the insertion of simulated teaching practice in a course under Teaching English for Young Learner Program is needed.

Teachers' professional knowledge can be developed through micro-teaching, observation, simulation, and role play [4]. Pre-service teachers prepare their future carrier as professional teachers by integrating field experience, practicum, and lecture course [11]. In order to be professional English teachers, pre-service teachers can conduct reflection, a special mental activity that plays important role in dealing with issue, challenge, conflict, and problem by looking at the action that have been done, the reason taking that action, and the result of the action [12], [13]. It is very important for preservice teacher to do self-observation and self-evaluation for their professional growth because pre-service teachers should not only prepare subject and pedagogical content knowledge, but also respond to unknown reality [13]. The unknown reality may vary based on the place, time, level of students, context, and individual.

\section{METHOD}

This case study focused on pre-service young learner English teachers' reflection through simulated teaching practice. Case study in this study was intensive and holistic investigation as well as analysis on a group of people in an institution and the researcher had little control over phenomenon and the context [14]). The case was a group of pre-service students in Material and Media Development course in a university of education, and the analysis unit was their reflection.

\section{A. Setting and Participants}

The study was conducted for one semester from August to December 2016. The participants included 26 pre-service teachers in Material and Media Development course, in Teaching English for Young Learner Program in a University of Education. The class met 100 minutes every week. On the first meeting, each participant was given a topic. The topics were based on Kindergarten and elementary student syllabus. After they had the topic, they developed material, media, and two lesson plans in two weeks. One lesson plan was for teaching kindergarten level, and the other was for elementary level. For the rest of the meetings, on each week, there were two participants did simulated teaching practice in the classroom. The other participants made two big groups, one group pretended as kindergarten students, and another group pretended as elementary students. In 100 minutes of each meeting, one participant was given 15 minutes for teaching kindergarten level, 20 minutes for teaching elementary level, and 15 minutes for discussion session. The rest of the class wrote the comment in peer response cards and gave verbal comment in the discussion session. Both peers and lecturer gave verbal comment to the participant. After having teaching practice and discussion in the classroom, the participants were assigned to teach students in real-life context: real kindergarten and real elementary students in real schools, but before that, they revised the media, material, and teaching activity based on the comments and response card.

The purpose of teaching practice and discussion in the classroom was to give chance to the presenter to be well prepared before teaching real kindergarten and elementary students. Moreover, the participants would be able to observe the teaching plan of each other and could relate their material and the previous ones because each week the students would see different teachers [15].

\section{B. Data Collection}

The data in this study comprised of (1) videos of teaching practice in classroom, in kindergarten, and in elementary schools including peers' and teacher's comments; (2) peers' response cards; and (3) participants' self-reflection. Participants' performances in teaching practice were videotaped. The participants could watch the videos anytime anywhere and could watch them several time [16] to produce detail self-reflection. Another type of data involves documents. The documents were peers' response card and participants' self-reflection writing. To make the selfreflection, participants need to watch the videos of teaching practicum including the discussion with peer and lecturer, and read their peers' response card. The self-reflection includes the topic, the material, the media, the experience, the problem they encountered and the solution to solve the problem based on peers' and lecturer's advice and their own ideas.

\section{Data Analysis}

The researcher constructed a set of code for thematic analysis. To capture the meaning of the data, the data were coded in the following three stages [17]. First, the researcher watched the videos, read through all the documents, and assigned major categories, such as material, media, classroom management, etc. Second, the researcher marked the data by a code, for example, time management, song, active students, etc. Finally, the data were sorted on the basis of fit into topic that reflected the reflection of pre-service young learner English teachers.

The validity in qualitative research focus on the findings' interpretation [4]. More than one source of data, namely videos, peer response card, and participants' self-reflection enhance the validity of the result of this study. Triangulation was performed to promote depth analysis.

\section{RESULT}

After designing material, media, lesson plan, and experiencing simulated teaching practice in the classroom, kindergarten school, and elementary school, and after having peer response card and peers' and lecturer's comments, the participants conducted self-reflection. It was the first time for the participants to teach young learners. They had never 
experienced teaching English for young learners. The analysis and discussion in this session focus on pre-service teacher's reflection in teaching English for young learner.

\section{A. Reflection on Material Design}

Interesting classroom activities, task, and material motivate students [15]. One student was given topic "shape and color". The media that he made were color dice: a big dice with six different colors in each side, and a shape dice: a big dice with six different shapes in each side. When he did teaching practice in the classroom, everything ran well; but when he taught in kindergarten, he reported that for 15 minutes teaching to real kindergarten students, it was more manageable to teach either shape or color. Teaching both shape and color in one meeting in kindergarten level was not recommended. Different from kindergarten level, teaching both color and shape at the same time in elementary level was not a big problem.

Two participants reflected that the materials that they designed were too easy for elementary students, for example, for my school and feeling topic. The participants designed to give the vocabularies related to the topic and play game and sing song afterward. In the teaching practice, the students enthusiastically learned and followed teacher's instruction. They could finish the activities less than the time allocated. It made the participants thought hard about the next activities that should be conducted. To spend the time, for the next activities, participants instructed each student to make a simple sentence related to the topic. Other participant assigned students into several groups and each group performed the song learned on that day or previous meeting in front of the class.

Other reflection about material designed was participant's sensitivity in choosing the material related to students' level. One participant who got means of communication topic designed conversation on the phone activity. The peers' response showed that it was difficult for kindergarten students to perform such conversation. Therefore, the participant revised the material by introducing only the vocabularies related to the topic, such as telephone, newspaper, etc., and preparing the pictures of those means of communication.

The last one is the number of vocabulary introduced in one meeting. The participant who taught job found that giving new vocabularies and requiring the students to memorize them was not easy. His kindergarten students felt bored and confused in learning 10 job vocabularies in one meeting. Then, he decided to skip 5 vocabularies and focus only on 5 job vocabularies. He concluded that the number of new word introduced by teacher should be based on students' ability.

\section{B. Reflection on Media}

After being given the topic, each participants designed material and created their own media. The media developed by the participants were flashcard, dices for shape and color topics, newspaper basket to put vegetable flashcard, pop-up book for teaching food, beverage, and school. They also made direction map, tourism object map, direction symbols, hats made of paper with the shape of pirate hat, masks with the shape of Dora and friends from Dora the explorer characters, a popular children's movie. In addition, the participants also created a family tree on a flannel cloth, flannel board for teaching transportation, poster of human body, kims' board game for teaching days and months, stick puppet for teaching job, finger puppet for teaching greeting and introduction, popup board for teaching sport, alphabet board for playing play dough, snake and ladder modification, mix and match clothes, puzzle, and season wheel spin.

There were some problems encountered in term of media. The first problem was the size of the media. Some participants designed media which made their classmates difficult to see. Based on the peers' comment in peer response card, along with the peers' and lecturer's comment in discussion session, the media should be revised. The participants revised them by making more visible media, so that all students, including those who sat at the back, could see the media. The second problem was the font of the words or sentences. It was revised by choosing the font that was easily readable. The third was the words and the pictures in the flashcard. It was agreed that the picture should be put on one side of the flashcard, and the word should be written on the other side. The reason was that when the teacher played guessing game by showing the picture of the flashcard, the students would not know the English word because the word was on the other side of the flashcard. The written word was important to be put in the flashcard to introduce the written form of the vocabulary being learned. Four, the map or board that was stuck on the wall fell down several times and it distracted both the teacher and the students. To avoid that, the participant should prepare stronger adhesive tape or double tape.

Two participants who taught clothes and communication prepared puzzle as media. They asked students to arrange puzzle and mention the picture. This activities interested elementary students. They liked puzzle very much. However, for kindergarten level, only one group of students could arrange the nine pieces puzzle into correct order. Other groups needed the help of the teacher. It was concluded that puzzle could only be used as media for kindergarten student with the help of the teacher.

\section{Reflection on Time management}

Participants were given 15 minutes for teaching kindergarten, and 20 minutes for teaching elementary students. Mostly, when they taught kindergarten students, they needed more than 15 minutes. It was because they were so busy handling active students who were interested in the media and activities. To be able to manage the time wisely, the participants committed to improve their classroom management skills in terms of handling students.

On the other side, several participants finished the lesson less than the time allocated. The participants needed to fill in the time and made plan B for every session. One of the plan B conducted by the participants was playing game 'domikado' by making big circle, singing and playing game, then one student mention the vocabulary learned on that meeting. Other activities were singing a song, and assisting students (in 
elementary level) to make simple sentence based on the vocabulary or topic in that meeting.

\section{Reflection on Song}

One of the most feasible and interesting strategy for teaching English for young learners is introducing English song. In the teaching practice, most participants used song as one of the strategies in teaching. They searched the existed song in youtube based on the topic given, some participants modified the song to be simpler, and some create a new song for the students. In the teaching practice, participants encountered problems in using song. First one, they forgot their song. When the participants sang the song in front of the class and forgot the next lyric, the students became confused. To avoid this problem in the future, the participants had to prepare themselves well before teaching the song. Second one, some songs were difficult and too long for young learners. For this problem, the participants concluded that they needed to carefully select and modify the song. The third one was although the song was a short song, sometimes the song was complicated to be pronounced by the students. Therefore, in choosing and making a new song, the participants should consider students' pronunciation ability.

\section{E. Reflection on Students' Participation}

Having active students is one thing that is always expected by teachers. However, for pre-service teachers, handling active kindergarten and elementary students were very big challenge. The participants had problem in managing the students who were really interested in touching, holding, and playing the media, such as pirate hat in giving direction topic, play dough in alphabet topic, pop-up book and board in sport and food and beverage topics, and many others. Beside the media, the students were very active in singing song. In several meetings, all students came in front of the class to sing the song together. In addition, the students stood up on the chair to see the teacher and media covered by other students and to be seen by the teacher and chosen to play a game.

The participants realized that those crowded situations should be handled appropriately. The liveliness of the students should be controlled. It was found that some teachers in South Korea, Japan, and Taiwan had similar problem in controlling students' active participation [7]. The challenge in classroom harmonization appear because of the interactive way they implemented in the classroom. The participants did several things, such as, paying attention to all students, assigning the students to be several groups, and giving chance to each group to sing song, deliver their ideas, and play games.

\section{F. Reflection on Pronunciation}

One of speaking aspects is pronunciation. The teacher is expected to give model in pronouncing the English words. Two participants got comments from their peers in terms of pronunciation. For example in pronouncing Tuesday and Thursday, the participant did not pronounce those words correctly. From peer's response card and the discussion session in the classroom, the participants prepared themselves to pronounce the words correctly for the next teaching practice in real students. It is important for the teachers to pronounce the words with correct pronunciation because young learners reproduce the pronunciation of the teachers with deadly accuracy [18].

\section{G. Reflection on Psychological Feeling}

All participants had not had experience in teaching English for young learner in the real context, to the real young students. It was the first time for them to teach kindergarten and elementary students. Before the day of teaching, they felt nervous, what it would be like teaching little children. To prepare them, they were instructed to come to the schools and observe the other participants who got schedule to do teaching practice at that school.

To have well-prepared psychological feeling, those lessexperienced young learner pre-service teachers also need to know three important things in teaching English for young learner [18]. First, the participants should understand the way children think and learn. Second, the participants should have teaching skill and knowledge. Third, they should have ability to teach initial literacy in English. In addition, there are two key aspects of child language learning. Participants should consider children's reaction when they encounter a new language and children's literacy skills.

\section{H. Reflection on Handling Students' Misbehavior}

The problems encountered by the participants on the teaching practice day were students' misbehavior, for example, crying, disturbing other students, did not want to sit down, asking the parents to accompany them in the classroom, and always looked at the parents outside. To handle this situations, the participants gave reward to the students who listened to the teacher's instruction and did not misbehave in the classroom. The rewards were in the form of motivating words, like very good, excellent, etc., sticker, stars, chances to sing a song with teachers in front of the class, or chances to do a game. The participants needed to be very patient in dealing with young learner [15].

\section{Reflection on Assigning Group}

In assigning groups in elementary level, the participants did not find any problem because they could assign the group by various activities, such as finding-friend game, finding other students who had similar cards, for example cards with similar animal pictures, or similar words, or colors. Assigning group activity had already been designed in fun way. However, problem occurred in kindergarten students. Some students did not want to be in group with other students; they cried and stayed still with their close friend. The thing that was done by participants to proceed the activity and to calm the crying students was letting them with their own friend, in addition, the participants explained in the soft way that all students in that class were friends, they needed to know and love each other, and it would be really nice when they have many friends.

\section{DISCUSSION AND IMPLICATION}

This study discusses pre-service young learner English teacher's reflection from simulated teaching practice. The 
simulated teaching practice led participants to develop their professional growth. In this first experience having simulated teaching practice, the participant noticed the characteristics of young learners [15].

First, young learners wanted a stress-free and comfortable environment. The participants' reflection showed that the way to speak to young learner was different from it was to adult. Young learners loved when participants spoke in soft and cheerful way. Young learners' motivation to learn new language was increased when the class full of smile and laugh. Besides, they also loved given touch, hug, and hi-five. Through three times teaching in simulated teaching practice, the participants trained themselves to create a stress-free and comfortable atmosphere in the classroom.

Second, young learners wanted to see colorful object around them. They liked colorful media designed by the participants. The media were designed carefully concerning color, size, shape, lay out, etc. The flashcards, dices, books, maps, symbols, hat, mask, family tree, board, stick puppet, finger puppet, puzzle, and wheel spin were designed colorfully to attract students' interest. However, newspaper baskets were also liked by the students although they were not colorful. Young learners liked the unique shape of the baskets.

Third, young learners needed to be motivated continuously during lessons. They had short span of time for concentration, only around 5 to 10 minutes. Therefore, participant should pay equal attention to all learner, give applause to the learners who performed in front of the class or answer teacher's question, and give reward in the form of stars, sticker, etc. Variety of fun, careful, and meaningful material and activities could keep the learners' interest [18].

Fourth, young learners could not sit still for a long time. They stood up, approached the teacher, stood in front of the class with the teacher when the teacher taught using media or sang song. The participants handled the crowded classroom by giving reward. Fifth, they liked songs and games. The games and songs given by participant could make the learning process fun and meaningful.

\section{CONCLUSION}

This study has analyzed pre-service young learner English teachers' reflection through simulated teaching practice. The findings of the study are as follows. First, the participants had never before experienced simulated teaching practice for young learner. Second, they used reflection tools, such as videos, peers and teacher' comments, and observation of peers' presentations, to help them develop self-reflection about their awareness of the skills they employed, the competencies they need to improve, their strengths and weaknesses, as well as the difficulties they found and the decision to solve the problems.

Since there were only 26 participants involved in this study, the finding cannot be generalized. The conclusion of this small number of participants cannot represent pre-service young learner English teachers' population. However, the perception and reflection of their first time teaching practice to young learners through triangulated qualitative data collection can provide necessary guidance to help less-experienced preservice young learner English teacher.

\section{REFERENCES}

[1] M. Shoffner, M. Brown, B. Platt, M. Long, B. Salyer. "Meeting the challenge: beginning English teachers reflect on their first year," English journal. Vol. 99, pp. 70-77, July 2010.

[2] M.N. Gungor. "Turkish pre-service teachers' reflective practices in teaching English to young learners," Australian journal of teacher education. Australia, vol 41, pp. 136-151, February 2016.

[3] T.S.C. Farrell, J. Ives. "Exploring teacher beliefs and classroom practices through reflective practice: a case study," Language teaching research. Vol 19, pp. 594-610, 2015.

[4] C. Chien. "Pre-Service elementary school English teachers' learning and reflection through simulated teaching practice and oral interview," Reflective practice: international and multidisciplinary perspectives. Taiwan, vol. 15, pp. 821-835, August 2014.

[5] C. Stuart, D. Thurlow. "Making it their own: preservice teachers' experiences, beliefs, and classroom practices," Journal of teacher education. Vol. 51, pp. 113-121, March-April 2000.

[6] M.S. Zein. "Pre-service education for primary school English teachers in Indonesia: policy implications," Asia Pacific journal of education. Singapore, vol. 36, pp. 119-134, October 2014.

[7] S. Garton. "Unresolved issues and new challenges in teaching English to young learners: the case of South Korea," Current Issues in Language Planning. London, vol. 15, pp. 201-219, November 2014.

[8] G. Hu. "English language education in China: policies, progress, and problems," Language Policy. Vol 4, pp.5-24, March 2005

[9] M.S. Zein. "Preparing elementary English teachers: innovations at preservice level," Australian journal of teacher education. Australia, vol. 40, p. 104-120, June 2015.

[10] M.S. Zein. "Elementary English education in Indonesia: policy developments, current practices, and future prospects," English today. United Kingdom, pp.1-7, 2016.

[11] E.C. Liaw. "Learning to teach: A descriptive study of student language teachers in Taiwan," English language teaching. Taiwan, vol 5, pp. 152 162, October, 2012.

[12] X. Qing. "Maximaxing learner autonomy through reflective teaching," Cross-cultural communication. Canada, vol. 9, pp. 19-22, 2013

[13] T.S.C. Farrell. "TESOL, a profession that eats its young! The importance of reflective practice in language teacher education," Iranian journal of language teaching research. Urmia university, vol 4, pp. 97 107, October 2016.

[14] B. Yazan. "Three approaches to case study methods in education: Yin, Meriam, and Stake," The qualitative report. Vol. 20. Pp. 134-152, 2015.

[15] N. Bekleyen. "Can I teach English to children? Turkish preservice teacher candidates and very young learners," Journal of early childhood teacher education. Turkey, vol 32, pp. 256-265, August 2011.

[16] I.P.N.W. Myartawan, L.D.S. Adnyani, "Integrating video in the corrective feedback practice: voices from Indonesia," TEFLIN. Solo, pp. 951-954, 2014.

[17] U. Flick, "The SAGE handbook of qualitative data analysis," Sage, Los Angles, 2013

[18] L. Cameron, "Challenges for ELT from the expansion in teaching children," ELT journal. Oxford University Press, vol 57, pp. 105-112, April 2003. 